\title{
Teachers and teaching in upper secondary education: a comparison of systems in place across secondary and FE sectors
}

\section{Lynne Rogers}

\begin{abstract}
The training of teachers in upper secondary education varies considerably dependent on whether training is undertaken as a secondary school teacher or as a teacher within the Further Education (FE) system. Indeed, until the late 1990s, the training of teachers in FE had been the focus of little regulation by Government. Differences also occur across the UK with different pathways in place in the home countries. Regardless of the pathway taken to teaching in upper secondary education there are concerns that the teaching in schools and FE is still not good enough.
\end{abstract}

The Coalition Government has proposed many reforms to the training of teachers in schools and a consultation exercise has been undertaken on the training of teachers in the FE sector. This article will review current approaches to the training of teachers in the home countries of the UK. Attention will be given to the proposed reforms in order to consider how these might contribute to raising the standard of teacher training and hence the quality of teaching in schools and FE.

Keywords: Initial Teacher Education; 14-19; Secondary, Further Education

\section{The context of Initial Teacher Education}

Concerns about pupil attainment have led to an increased focus on initial teacher education (ITE) in many developed countries. This on the basis of the argument that one of the most important influences on children's and young people's learning is the teacher. In itself, this is problematic since although evidence is presented on the impact of teacher effect on pupils' learning (Seidel and Shavelson, 2007; Fallon, 2006) there is a lack of consensus about what an effective teacher is; the specific qualities of an effective teacher that contribute to better student learning; how this might be measured in an objective fashion; and a debate about research approaches that ignore the complexities of teacher education as a social-cultural entity. 
The contribution that education can make to global reform has intensified the focus on ITE at an international level. Governmental recognition of global economic competitiveness and the shift from industrial to knowledge economies draw attention to the role that education plays in developing that economic competitiveness (Sahlberg and Boce, 2010). This can be seen in the increasing use made by governments of international educational comparative studies such as the OECD Programme for International Student Assessment (PISA). On the basis of the results achieved, considerations are made about the role and responsibilities of schools and teachers in preserving or improving positions, a situation common to many countries (Power 2007; Blömeke, 2006). Hence, the training of teachers and the different routes into teaching become a major focus and is accompanied by measures used to gauge the effectiveness, and thus accountability of teachers (Gray and Colucci-Gray, 2010).

Measures used by governments to gauge the effectiveness of teachers usually take the form of pupil achievement on standardised achievement tests: this approach has been widely criticised (Lingard, 2010; Stobart, 2008).

It would seem that those involved with ITE are faced with a dilemma. On the one hand there is an agenda based on a scientific approach that takes the stance of what works in education and on the other hand trainee teachers and teachers at ground level are faced with a multitude of different interests and needs. For a succinct discussion of these issues see Gray and Colucci-Gray (2010). Apparent is that a simplistic notion of research based on the technical rationalist approach would indicate that it is appropriate to measure the 'impact' that teachers have: this ignores the complexity of the situation and the different contextual factors that contribute to learning and the difficulty mentioned above about reaching a consensus about what is meant by an effective teacher.

Historically, areas of social and political debate around ITE across many countries have centred on:

- struggles for 'positioning' and the 'ownership' of teacher education;

- attempts to define teaching as a profession;

- whether teaching has a distinctive intellectual knowledge base;

- debate over teachers' terms and conditions, as well as pay, and the role of teachers' unions;

- the emergence of professional bodies to uphold professional standards and to control entry into the profession, and

- the economics of teacher supply and demand (Menter et al., 2010). 
For those teaching in schools and FE this is a time of rapid change. Since 2010 there has been a plethora of publications, consultations and reports on ITE. Within the school context these have included the white paper The Importance of Teaching (DfE, 2010a), the Case for Change (DfE, 2010b), and the Donaldson Review (Scottish Government, 2010). Those focusing on FE have included a review of FE teaching in England (LLUK, 2011), and a review of vocational education (Wolf, 2011).

In reality government calls for improving teaching and learning have been a near constant feature of the policy landscape for those working in FE and schools for the last 50 years (Colley et al., 2007; Donaldson, 2010). Broadly speaking policy drivers have centred on the importance of raising skills levels in the UK to ensure we remain economically prosperous at the same time as aiming for increased social inclusion and social mobility (Hodgson, 2007). There are though inherent tensions here: since, for example, within FE it has been argued that the sector is being required to respond to major social, economic and employment needs with ever decreasing resources (Biesta et al., 2007).

Ofsted reporting on inspection visits carried out in England during 2009-10 stated 'too much teaching is still not as good as it should be, both in schools and colleges, and, as a result, too many children are not equipped well enough to make the best of their lives' (2010, p.12). In secondary schools the quality of teaching was too variable and the use of assessment needed to improve. Of the schools inspected during 2009-10 45 per cent were deemed only satisfactory. In sixth forms 39 per cent of teaching was deemed only satisfactory. In less effective sixth forms concerns centred on the poor match between the curriculum and students' abilities. In FE the quality of teaching and learning provision was good or outstanding in only 48 of the 79 colleges inspected. Where teaching, learning and assessment was weak specific issues related to insufficient focus on the effectiveness of teaching and its impact on learning; low expectations, insufficient challenge, and lack of clear learning objectives.

While the issues identified by Ofsted would suggest that teaching needs to improve; it is important to acknowledge that concerns about the effectiveness of teacher education and teaching are rooted within different views about the aims and purposes of education. Some have argued for increasing attention to issues of access and equity in education (Florian and Rouse, 2009). Other issues arise in relation to the kinds of learning that are perceived to be worthwhile. The policy focus on learning outcomes and the achievement of qualifications is understandable but ignores an holistic approach to education in which there may be other 
significant outcomes for students, for instance in relation to personal growth (Hodkinson et al., 2007).

\section{Current approaches to ITE in secondary schools}

Across the UK all countries offer under graduate and post graduate provision, and have similar requirements for an acceptable level of English. Distance learning is offered throughout the UK by the Open University. The Postgraduate Certificate in Education (PGCE) is the predominant route with Scotland offering the Professional Graduate Diploma in Education (PGDE). All trainees are assessed against professional standards.

England offers the greatest variety of routes into teaching, followed by Wales (see Table 1). Employment-based routes (EBR) attract more students in England with Graduate Teacher Programmes (GTP), Oversees Trained Teacher Programmes (OTTP) and School Centres for Initial Teacher Education (SCITT) provision being part of the normal entry into teaching. SCITT and employment-based routes (EBR) account for 15 per cent of training places.

EBR involves training as a teacher while working in a school. Trainees are employed as unqualified teachers and undertake a structured training programme. SCITT consortia generally run their courses entirely within their member schools. Usually trainees are based in a lead school but undertake placements at other schools within the consortium. Most SCITT run courses have been validated by a university or college and lead to the award of PGCE. There is no SCITT provision in Northern Ireland, Wales or Scotland. In Scotland and Wales all secondary teacher education is provided within universities or colleges of higher education.

Teach First, founded in 2002, is an English version of the US programme Teach for America. Distinctive is the requirement for trainees to commit to teaching for two years: they obtain Qualified Teacher Status (QTS) at the end of their first year. Trainees are highly qualified graduates and are placed in challenging schools.

Table 1: Overview of Secondary ITE provision

\begin{tabular}{|l|l|l|l|l|}
\hline & England & Northern Ireland & Scotland & Wales \\
\hline $\begin{array}{l}\text { Number of HEIs } \\
\text { offering ITE }\end{array}$ & Around 80 & $\begin{array}{l}\text { Five (including } \\
\text { the Open } \\
\text { University) }\end{array}$ & $\begin{array}{l}\text { Eight (including } \\
\text { the Open } \\
\text { University) }\end{array}$ & $\begin{array}{l}\text { Three centres } \\
\text { based upon HEI } \\
\text { partnerships }\end{array}$ \\
\hline Pathways to & BEd & BEd & BEd & BEd \\
\hline
\end{tabular}




\begin{tabular}{|l|l|l|l|l|}
\hline teaching & $\begin{array}{l}\text { PGCE } \\
\text { GTP } \\
\text { OTTP } \\
\text { SCITT } \\
\text { Teach First }\end{array}$ & $\begin{array}{l}\text { PGCE } \\
\text { PGCE Irish } \\
\text { Medium }\end{array}$ & PGDE & $\begin{array}{l}\text { BA Education } \\
\text { BSc } \\
\text { PGCE } \\
\text { PGCE Welsh } \\
\text { Medium } \\
\text { GTP and RTP }\end{array}$ \\
\hline $\begin{array}{l}\text { Entry } \\
\text { requirements }\end{array}$ & $\begin{array}{l}\text { Degree plus } \\
\text { competence in } \\
\text { English and } \\
\text { mathematics } \\
\text { e.g. GCSE grade } \\
\text { C or above }\end{array}$ & $\begin{array}{l}\text { PGCE: First } \\
\text { degree plus } \\
\text { competence in } \\
\text { English and } \\
\text { mathematics } \\
\text { e.g. GCSE grade } \\
\text { C or above }\end{array}$ & $\begin{array}{l}\text { Degree plus } \\
\text { competence in } \\
\text { English e.g. } \\
\text { GCSE C grade or } \\
\text { above }\end{array}$ & $\begin{array}{l}\text { Degree plus } \\
\text { competence in } \\
\text { English and } \\
\text { mathematics } \\
\text { e.g. GCSE grade } \\
\text { C or above }\end{array}$ \\
& & & \\
\hline
\end{tabular}

In England and Wales, trainees on satisfactory completion of the PGCE qualification are recommended for either English or Welsh QTS which is a requirement to teach in maintained schools. Trainees qualifying in Northern Ireland are granted 'eligibility to teach'. Only in England do trainees have to undertake QTS Skills Tests in literacy, numeracy and ICT. In comparison to other home countries, it has been suggested that in Scotland school staff play a relatively limited role in the tutoring, assessment and support of students (Smith et al., 2006).

\section{Current approaches to ITE in FE}

Across the UK professional standards apply to FE teachers: this has not always been the case. Qualification titles vary: England offers PGCE, Certificate in Education and Diploma for the Lifelong Learning Sector (DTLLS) while in Scotland the Teaching Qualification in Further Education (TQFE) is the core teaching qualification (see Table 2). Aspects of ITE programmes are similar covering professional values and practice; learning and teaching; planning learning; assessment for learning, and access and progression. Variation is apparent in the number of hours of teaching practice and the number of observations. England currently has the highest minimum number of hours of teaching practice at 150; however, this is likely to be reduced to 100 following the review of ITE provision (LLUK, 2011b).

Most FE ITE qualifications are generic, unlike schools, with the exception of Literacy, ESOL and Numeracy in England. Unlike secondary, the actual level of the qualification depends upon the level at which it is delivered and the institution delivering it. This is problematic within England with qualifications offered at Levels 5, 6 and 7; with different titles, and with differences in the number of modules and credit ratings (Lucas et al., 2010). Indeed it 
could be argued that a two-tier system has been put in place whereby those with a degree follow the PGCE pathway and those without follow DTLLS at Level 5.

Table 2 Overview of requirements of FE ITE

\begin{tabular}{|c|c|c|c|c|}
\hline & England & $\begin{array}{l}\text { Northern } \\
\text { Ireland }\end{array}$ & Scotland & Wales \\
\hline Entry requirements & $\begin{array}{l}\text { Varies } \\
\text { according to } \\
\text { awarding } \\
\text { institution }\end{array}$ & First degree & $\begin{array}{l}\text { First degree } \\
\text { plus other } \\
\text { variations }\end{array}$ & $\begin{array}{l}\text { Usually a } \\
\text { degree }\end{array}$ \\
\hline Qualification title & $\begin{array}{l}\text { Diploma } \\
\text { Professional } \\
\text { Graduate } \\
\text { Certificate in } \\
\text { Education } \\
\text { PGCE }\end{array}$ & Postgraduate & $\begin{array}{l}\text { TQ(FE) } \\
\text { Undergraduate } \\
\text { TQ(FE) } \\
\text { Postgraduate }\end{array}$ & $\begin{array}{l}\text { PGCE } \\
\text { Professional } \\
\text { Graduate } \\
\text { Certificate in } \\
\text { Education }\end{array}$ \\
\hline $\begin{array}{l}\text { Broad comparison to } \\
\text { the EQF }\end{array}$ & $5,6,7$ & 7 & 6,7 & 7 \\
\hline $\begin{array}{l}\text { Duration of practical } \\
\text { teaching during training }\end{array}$ & $\begin{array}{l}150 \text { hours } \\
\text { minimum }\end{array}$ & $\begin{array}{l}100 \text { hours } \\
\text { minimum }\end{array}$ & $\begin{array}{l}120 \text { hours of } \\
\text { varied teaching }\end{array}$ & $\begin{array}{l}\text { Varies } \\
\text { according to } \\
\text { institution }\end{array}$ \\
\hline $\begin{array}{l}\text { Observation of teaching } \\
\text { during training }\end{array}$ & $\begin{array}{l}\text { Minimum } \\
\text { eight assessed } \\
\text { observations }\end{array}$ & $\begin{array}{l}\text { Observations } \\
\text { required }\end{array}$ & $\begin{array}{l}\text { Minimum two } \\
\text { assessed } \\
\text { observations }\end{array}$ & $\begin{array}{l}\text { Varies } \\
\text { according to } \\
\text { awarding } \\
\text { institution }\end{array}$ \\
\hline
\end{tabular}

\section{New professionalism and standards}

Each of the four countries has a set of standards that define the knowledge and understanding, skills and abilities, values and personal commitments expected of teachers although these are different across schools and FE. There are also major differences in teacher training for those working in schools or FE in relation to governance, those providing ITE and the qualifications and curricula (see Table 3). For school teachers governance and regulation is currently with the Teacher Development Agency (TDA) and the General Teaching Council (GTC). For those working in the FE system the teaching qualification reforms were taken forward by Lifelong Learning UK, which replaced the Further Education National Training Organisation in 2005. The Institute for Learning (IfL), equivalent to the GTC, confers the post-qualification status of QTLS and manages the professional development requirements. 
Table 3 Overview of similarities and differences in Upper Secondary ITE (England) prior to coalition reforms

\begin{tabular}{|c|c|c|}
\hline & $\begin{array}{l}\text { School ITE (direct regulation by } \\
\text { Secretary of State and TDA) }\end{array}$ & $\begin{array}{l}\text { FE ITE (indirect regulation by } \\
\text { employer lead body) }\end{array}$ \\
\hline \multirow[t]{5}{*}{$\begin{array}{l}\text { Governance } \\
\text { and } \\
\text { regulation }\end{array}$} & $\begin{array}{l}\text { The Secretary of State defines the } \\
\text { national requirements for QTS. ITE } \\
\text { compulsory. }\end{array}$ & $\begin{array}{l}\text { The Secretary of State defines the } \\
\text { requirements for QTLS. ITE compulsory. }\end{array}$ \\
\hline & $\begin{array}{l}\text { TDA - a non departmental public body } \\
\text { sponsored directly by the Department for } \\
\text { Education. }\end{array}$ & $\begin{array}{l}\text { An employer-led organization, LLUK, which } \\
\text { sets standards, qualification and assessment } \\
\text { requirements. }\end{array}$ \\
\hline & $\begin{array}{l}\text { TDA manages teacher training and } \\
\text { professional development. Sets } \\
\text { professional standards for QTS and later } \\
\text { career phases. }\end{array}$ & $\begin{array}{l}\text { Standards Verification UK responsible for } \\
\text { accrediting providers (until March 2011). } \\
\text { The IfL confers QTLS. }\end{array}$ \\
\hline & $\begin{array}{l}\text { State funding for ITE is routed through } \\
\text { the TDA which accredits providers and } \\
\text { allocates training places/ funding. }\end{array}$ & $\begin{array}{l}\text { State funding is through HEFCE, and the Skills } \\
\text { Funding Agency, and local authorities. }\end{array}$ \\
\hline & \multicolumn{2}{|c|}{ Ofsted inspects ITE. } \\
\hline \multirow[t]{3}{*}{ Providers } & Pre-service full-time ITE is the norm. & In-service part-time route is the norm. \\
\hline & $\begin{array}{l}\text { Majority of ITE provided by universities } \\
\text { to postgraduates. }\end{array}$ & $\begin{array}{l}\text { Most ITE delivered by FE colleges. Teaching } \\
\text { experience is normally in their place of } \\
\text { employment. } \\
\text { Open to graduates and non-graduates. }\end{array}$ \\
\hline & $\begin{array}{l}\text { Universities work in partnership with } \\
\text { schools that provide teaching practice. } \\
\text { Placements account for two-thirds of the } \\
\text { time spent studying for a PGCE. }\end{array}$ & $\begin{array}{l}\text { Universities and National Awarding Bodies } \\
\text { offer qualifications. } \\
\text { Universities usually work in local or regional } \\
\text { partnerships with FE colleges. }\end{array}$ \\
\hline \multirow[t]{2}{*}{$\begin{array}{l}\text { Qualifications } \\
\text { and curricula }\end{array}$} & $\begin{array}{l}\text { Qualifications linked to QTS are well } \\
\text { established; growing state regulation of } \\
\text { ITE since } 1989 .\end{array}$ & $\begin{array}{l}\text { Gaining an ITE qualification has been a legal } \\
\text { requirement since } 2001 \text {. Level } 5 \text { qualification is } \\
\text { offered in addition to PGCE }\end{array}$ \\
\hline & $\begin{array}{l}\text { ITE linked to the National Curriculum; } \\
\text { trainees grouped according to their } \\
\text { subject and the age-range they wish to } \\
\text { teach. }\end{array}$ & $\begin{array}{l}\text { LLUK stipulates the teaching role, hours of } \\
\text { course and numbers of observations. } \\
\text { Most training is generic. }\end{array}$ \\
\hline
\end{tabular}

(Adapted from Lucas and Nasta, 2010)

New professional standards for secondary teachers in England were introduced in 2007 with new induction arrangements introduced in 2008. Changes made to performancemanagement came into effect in September 2009. Within England, the professional standards define the characteristics of teachers at each career stage and provide standards for the award of QTS; teachers on the main scale; teachers on the upper pay scale; Excellent Teachers, and Advanced Skills Teachers (TDA, 2007). For those wishing to gain QTS, there were 33 standards, organised under three categories:

- professional attributes (relationships with young people, communicating and working with others, and personal professional development);

- professional knowledge and understanding (teaching and learning, assessment and monitoring, subjects and curriculum, literacy, numeracy and ICT, achievement and diversity, and health and well-being); and 
- professional skills (planning, teaching, assessing, monitoring and giving feedback, reviewing teaching and learning, the learning environment, and team working and collaboration).

In FE the publication of the New Overarching Professional Standards (2006) represented a first step towards the construction of a new framework of qualifications and heralded a new initiative within the sector to support the professionalism of the workforce and to improve the quality of teaching, training and learning. The LLUK standards contain 190 statements that set out the values and practice of teachers. Unlike the application of the standards for school teachers, the development of the standards for FE resulted in the publication of units of assessment which clashed with the credit framework in operation in many HEIs (Lucas et al., 2010). These developments were complemented by the new Continuing Professional Development (CPD) expectation for full time teachers of a minimum of 30 hours per year.

It is questionable whether the focus on professional standards for teachers has led to consistency in provision and contributed to raising the standard of teaching and learning within the classroom. Nasta (2007) suggests that trainees in FE only engage with standards to the extent necessary to gain their qualification and rely instead on workplace interactions to generate professional knowledge. By contrast research into The Professional Standards for Teachers in England indicated that staff are familiar with the standards (Walker et al., 2011). Almost half reported that using the standards had helped contribute to school improvement or had led to improvements in their pupils' progress. Noteworthy was that over 10 per cent of teachers disagreed or strongly disagreed that the standards had impacted on either area (Walker et al., 2011).

A further difficulty arises from how well written statements capture the complexities involved in the process of teaching (Bronwen, 2010, Lucas et al., 2010). Implicit within the LLUK standards is the assumption that it is possible to capture complex professional knowledge and skills in written statements. As Nasta (2007) has argued, this is underpinned by an objectivist view of knowledge as codifiable, universal and applicable across contexts. This runs contrary to more recent socio-cultural conceptions of professional knowledge (Bronwen, 2010).

\section{The profile of the trainee teacher and teachers within upper secondary}

Provisional January 2010 results for England for publicly funded schools show that the number of FTE teachers in secondary schools was 210,300 plus an additional 15,300 FTE 
teachers in City Technology Colleges (CTCs) and academies (DfE, 2010). Colleges employ 140,000 teachers and lecturers (AoC, 2010). FE colleges cater for more 16 to 18 year olds than schools. During 2009-10 831,000 16 to 18-year-olds studied in colleges compared with 423,000 in maintained schools, academies and CTCs. Increasing numbers of 14 to 15 year olds are enrolled at colleges although most are part time. A higher proportion of students attending colleges are from a disadvantaged background than those in schools and sixth form colleges (AoC, 2010).

Those training to teach in secondary schools are often younger than their FE counterparts. In 2008-09 almost half of secondary trainees were under 25 (Smithers and Robinson, 2010). In 2008-09 the average age of FE teaching staff was 45 with over a quarter of staff in the 50 to 59 age group (LLUK, 2009). Although the common career trajectory for school teachers is school to university to teacher training then back to school teaching (Nasta, 2007), many teachers in FE enter teaching as a second or third career, following work in industry or public services. Many teachers enter the profession part-time. Gleeson and James (2007) adopt the term the 'long interview' to describe the entry into teaching in FE among individuals whereby they begin with a few part-time hours, before being offered more work or a full-time post about a period of months or, indeed, years. Many trainees undertaking training in FE already have substantial experience of teaching or working in learning support roles. This is entirely different to the predominant model within schools. Indeed the diversity of tutors in FE is itself an important and distinctive feature of the learning culture (Gleeson and James, 2007).

\section{Subject specialism}

Trainee teachers within secondary education apply to study a PGCE in a specific subject (see Table 4). Most subjects offered are academic, with a minority of subjects classed as vocational. This is not the case within FE since most ITE is generic.

Table 4 Secondary ITE provision in England 2010-11 by subject

\begin{tabular}{|l|c|}
\hline Subject & Number of trainees \\
\hline Art & 480 \\
\hline Citizenship & 220 \\
\hline English (including Drama) & 1,800 \\
\hline Geography & 700 \\
\hline History & 520 \\
\hline Mathematics & 2,340 \\
\hline Modern foreign languages & 1,360 \\
\hline Music & 550 \\
\hline
\end{tabular}




\begin{tabular}{|l|c|}
\hline Physical education & 1,160 \\
\hline Religious education & 710 \\
\hline Science & 3,070 (total) \\
Biology & 1,010 \\
Chemistry & 910 \\
General sciences & 560 \\
Physics & 600 \\
\hline Technology & 2,490 \\
\hline Vocational subjects/Diploma subjects & 280 \\
\hline Other & 320 \\
\hline Total & 15,990 \\
\hline
\end{tabular}

(DfE, 2010c)

1. Technology includes Design and Technology, Information and Communications Technology, Business Studies, Graphics, Textiles and Food Technology

Note: Totals may not appear to equal the sum of component parts because of rounding.

The secondary school curriculum offer is generally narrower than that in FE. Colleges may identify up to 200 specialisms compared to 15-20 specialisms in a school (Crawley, 2005), although there has also been a trend towards the disintegration of disciplines in FE. For example, numeracy as a subject might appear in the Skills for Life department as well as the mathematics department; a construction teacher might be asked to teach plumbing or electrical installation. This curricular 'super-complexity' does not generally occur in schools (Fisher and Webb, 2006). Table 5 provides a summary of subject areas taught in FE.

Table 5 Subject areas taught by lecturers in FE in England during 2008-2009

\begin{tabular}{|l|c|c|}
\hline Area of learning of main subject taught & $\begin{array}{c}\text { Number of } \\
\text { staff }\end{array}$ & Per cent \\
\hline Visual and performing arts and media & 16,795 & $12.2 \%$ \\
\hline English, languages and communication & 13,311 & $9.6 \%$ \\
\hline Health, social care and public services & 12,522 & $9.1 \%$ \\
\hline Foundation programmes & 12,386 & $9 \%$ \\
\hline $\begin{array}{l}\text { Business administration, management and } \\
\text { professional }\end{array}$ & 11,668 & $8.4 \%$ \\
\hline Hospitality, sports, leisure and travel & 9,799 & $7.1 \%$ \\
\hline Science and mathematics & 8,166 & $5.9 \%$ \\
\hline Engineering, technology and manufacturing & 7,574 & $5.5 \%$ \\
\hline Information and communication technology & 7,229 & $5.2 \%$ \\
\hline Humanities & 7,200 & $5.2 \%$ \\
\hline Construction & 6,903 & $5 \%$ \\
\hline Hairdressing and beauty therapy & 5,830 & $4.2 \%$ \\
\hline Retailing, customer service and transportation & 3,282 & $2.4 \%$ \\
\hline Land based provision & 3,042 & $2.2 \%$ \\
\hline Teaching staff lower than NQF level 4 & 3,531 & $2.6 \%$ \\
\hline $\begin{array}{l}\text { Not a member of staff providing teaching and } \\
\text { promoting learning }\end{array}$ & 3,660 & $2.6 \%$ \\
\hline Not known /not provided & 5,324 & $3.9 \%$ \\
\hline
\end{tabular}


ITE across secondary and FE has been criticised about the development of subject specialisms during training. Within FE the lack of opportunities for trainees to develop subject specialist knowledge and pedagogy has been seen as a key deficit (DfES, 2003; Ofsted, 2003). However; it has been argued that these criticisms ignore the diversity of teaching within the FE system where the curricula is less likely to be structured around subjects than in schools and where teachers undertake roles that extend beyond delivering subject knowledge (Bronwen, 2010; Lucas, 2007; Fisher and Webb, 2006).

The training of secondary teachers in vocational subjects was deemed poor following a survey of 14 providers (Ofsted, 2007). Half the providers gave insufficient attention to some aspects of teaching vocational subjects with weaknesses apparent in training of work-based learning. Teaching vocational education in schools is a highly charged issue: school teachers are not required to have experience of, or expertise of the vocational pathway: this in contrast to FE. FE teachers who do have the experience needed to teach the vocational curriculum, but do not have QTS, can only be employed as instructors on a lower salary in schools (Skills Commission, 2009). This is not the place to discuss whether there is a distinctive vocational pedagogy: relevant is the call for professional convergence of routes into teaching for those working within 14-19 and the removal of separate training bodies for school and FE teachers, separate terms and conditions, separate professional bodies and separate government departments overseeing teacher training (Skills Commission, 2009). Teachers with QTS can move into FE with little retraining; however, currently those with QTLS cannot move into schools. The Wolf Review (2011) has recommended that QTLS should be recognised in schools and Michael Gove has accepted this. Questions remain as to exactly how this will be put in place and whether this will be open only to graduates.

\section{Induction and Early Professional Development}

School teachers undertake an induction period during their first year of teaching as a newly qualified teacher (NQT) or beginner teacher in Northern Ireland: this after gaining QTS. Induction comprises two main elements: a personalised programme of professional development and support, and an assessment against the agreed professional standards for teachers. These are the core standards in England. In England NQTs are entitled to a 10 per cent reduction in their teaching timetable (in addition to the statutory 10 per cent for planning, preparation and assessment); support from an induction tutor, and regular 
reviews of progress with formal meetings at the end of each term with the tutor or head teacher.

Induction is followed by a two-year programme of Early Professional Development (EPD) but without any statutory or contractual entitlements for release time. Underlying EPD provision is the recognition that early career teachers may have different developmental needs from more experienced teachers. In Wales EPD provision is managed by the General Teaching Council for Wales (GTCW) and teachers are mentored by an EPD mentor and encouraged to develop further their practice of self-evaluation and reflection established during induction.

In Scotland the teacher induction scheme offers all new teachers qualifying from Scottish universities a paid year-long placement in a mainstream school, giving them support to achieve the Standard for Full Registration. Probationer teachers are provided with schoolbased mentoring and support, as well as a programme of CPD led by the local authority. Probationary teachers have a maximum class commitment of 0.7 FTE. Relevant here are the intentions behind the Donaldson review (2010) to consider the best arrangements for the full continuum of teacher education in Scotland that draw together ITE, induction and CPD.

Differences between secondary school and FE teachers are apparent in relation to qualification, induction and CPD. In schools trainees are awarded QTS on completion of the PGCE and evidence of meeting the standards; by contrast, teachers within FE are required to undergo a period of professional formation to achieve QTLS before being fully qualified. Managed by the IfL, teachers have to complete a portfolio that meets the nine standardised and personalised elements of professional formation. This includes evidence of observations of teaching; evidence of professional development through personal reflection on CPD, teaching and learning, subject specialist needs and wider networks. QTLS is subject to annual review: this based on evidence provided by the individual teacher of 30 hours CPD and reflection.

The process of professional formation might be viewed as an induction period, but there is no remission of time and no requirement for mentoring to be in place. No formal systems are in place to support early professional development in years 2 and 3 of a teaching career. Unlike school teachers, FE teachers operate with one set of standards: those required to obtain the initial qualification. This may well account for the discrepancies highlighted earlier about the relative engagement with standards within secondary and FE. 


\section{Reforms to ITE}

Two drivers appear to be behind the reforms of ITE in schools: a focus on the quality of teaching and a movement towards a school-led education system. The white paper (DfE, 2010a) set out the policy direction of the Coalition Government which included proposals for changing the nature of ITE in England. Key areas included:

- improving the quality of teaching through recruiting high-achieving academic graduates to the profession;

- $\quad$ shifting the balance of teacher education from universities to schools;

- removing funding for graduates who do not have at least a 2:2 for ITE from September 2012;

- including more rigorous basic skills test before application with fewer opportunities for retakes;

- considering the use of assessments for aptitude, personality and resilience as part of the selection process;

- more initial teacher training to take place 'on the job', SCITT, and GTP programme to be expanded (DfE, 2010a).

In announcing the Education Bill Michael Gove stated that it would help teachers raise standards in schools and highlighted the measures to tackle bad behaviour and underperformance and improve the way in which schools were held to account. New school inspections would require Ofsted to focus only on pupil achievement, teaching, leadership, and behaviour and safety. The English education system would be measured against the best in the world. It proposed the abolition of the GTC in England and that key functions of the TDA in recruiting and training teachers would be transferred to the DfE by 2012. More recently funding arrangements for secondary teachers in England have changed with bursaries only being offered for mathematics, science, engineering and modern foreign languages.

Plans were put forward to increase the diversity of routes into teaching through Teach First, Teach Next and Troops to Teachers, although numbers are modest over the next five years. A network of Teaching Schools was envisaged which would see schools leading initial training as well as the CPD of teachers and head teachers. The increase in SCITTs and GTP programmes runs counter to the Ofsted report (2010) where a higher proportion of HEI-led partnerships were found to be outstanding than SCITTs or EBRs. HEIs though may continue 
to play a role. Teacher performance standards are under review including new QTS standards. ITE programmes are likely to foreground synthetic phonics, early mathematics, behaviour management and SEN. Removing HEIs from ITE seems unlikely to raise the status of teachers and presumably would make it harder for new trainees to gain access to the latest research about education. Across upper secondary, it appears that proposals for closer working together of all those within 14-19 education have taken a backwards step with the planned systems to be put in place leading to a more divisive system. Proposals for a 2:2 graduate population are one example of this.

\section{Conclusions}

Regardless of the different approaches to ITE across secondary and FE, there are many challenges that teachers within upper secondary face. The raising of the school leaving age will mean that more students than before will be in some form of education or training. The increase in unemployment among young people may leave some students unmotivated since progression paths seem limited: this despite the recommendations of the vocational review (Wolf, 2011). Those currently disengaged with education may become more so, especially if the curriculum offer becomes narrower, more formal and with higher levels of prescription.

New funding arrangements for ITE privilege certain subjects to a greater extent than previously and the increasing emphasis on comparison in international league tables may mean that schools move towards a performance culture rather than encouraging a learning culture. The announcement of the English Baccalaureate, comprising five core GCSE subjects at grades $A^{*}-\mathrm{C}$ (mathematics, English, sciences, a foreign language and a humanity), and the retrospective use of this in league tables has already impacted on the choices that young people can make with some head teachers requiring pupils to change subjects part way through their two-year GCSE programme.

Across upper secondary working together has been regarded as important with increasing calls for greater collaboration so that young people have access to a broad more enriched curriculum (Ofsted, 2010). Arguments have been made for convergence between the separate training routes and regulatory structures of school and FE. Prior to the election of the coalition government, the introduction of professional standards, QTLS and a requirement for $\mathrm{CPD}$ could have been seen as a move to harmonise the training of teachers in the FE system with the training of school teachers. The new government has placed much 
greater emphasis on institutional autonomy. This together with the increasing range of new education providers will bring about increased competition. Academies, new 16-19 academies and free schools will be able to set their own curriculum and recruit teachers without qualifications.

What is clear is the need to improve the continuum of ITE into induction and beyond so that all teachers have the opportunity to develop to their best potential through emphasising professional practice reflection, critical analysis and evidence-based decision making that places research informed practice at the centre. ITE cannot provide teachers with the knowledge and skills necessary for a lifetime of teaching. If we are to raise the standard of learning among children and young people, and if one route to this lies in the improved quality of ITE and teaching, then the professional development of all those involved should to be seen as a lifelong task that is structured and resourced appropriately. It is unlikely that this will happen if teachers are operating in a competitive, divisive and uncertain educational environment.

\section{References}

AoC 2010. College Key Facts! Summer 2010. London: AoC.

Biesta, G., James, D., Hodkinson, P., Glleson, D. and Postlethwaite. 2007. Transforming learning cultures in Further Education. In Improving Learning Cultures in Further Education, ed. David James and Gert Biesta, pages 144-160. London: Routledge.

Blömeke, S. 2006. Globalization and educational reform in German teacher education. International Journal of Educational Research 45: 315-24.

Bronwen, M. 2010. Teacher knowledge and initial teacher education in the English learning and skills sector. Teaching Education 21, no. 4: 335-348.

Colley, Helen, Wahlberg, Madeleine and David James. 2007. Improving teaching and learning in FE: a policy history. In Improving Learning Cultures in Further Education, ed. David James and Gert Biesta, pages 41-59. London: Routledge.

Crawley, Jim. 2005. In at the deep end - a Survival Guide for teachers in Post Compulsory Education. London: David Fulton.

DfE 2010a. The Importance of Teaching: The Schools White Paper 2010. London: DfE.

DfE 2010b. The Case for Change. London: DfE.

DfE 2010c. TABLE A1: Recruitment to initial teacher training: college based courses by sector and subject specialism.

http://www.education.gov.uk/rsgateway/DB/SFR/s000927/sfr11-2010itt.xls 
Donaldson, Graham. 2011. Teaching Scotland's Future: Report of a Review of Teacher Education in Scotland. Edinburgh: Scottish Government.

Fallon, D. 2006. The buffalo upon the chimneypiece: The value of evidence. Journal of Teacher Education 57, no. 2: 139-54.

Fisher, R. and Webb, K. 2006. Subject specialist pedagogy and initial teacher training for the learning and skills sector in England: the context, a response and some critical issues. Journal of Further and Higher Education 30, no.4: 337-349.

Florian, L., and Rouse, M. 2009. The inclusive practice project in Scotland: Teacher education for inclusive education. Teaching and Teacher Education 25, no. 4: 594-601.

Gleeson, D. and James, D. 2007. The paradox of professionalism in English Further Education: a TLC project perspective. Educational Review, 59, no.4: 451-467.

Gray, D. S. and Colucci-Gray, L. 2010. Challenges to ITE research in conditions of complexity. Journal of Education for Teaching 36, no. 4: 425-439.

Hodgson, A., Spours, K. and Steer, R. 2007 All Change for the Learning and Skills Sector? Journal of Education and Work, 21, no.2:115-131.

Hodkinson, P., Biesta, G. and James, D. 2007. Learning cultures and a cultural theory of learning. In Improving Learning Cultures in Further Education, ed. David James and Gert Biesta, pages 21-37. London: Routledge.

Lingard, B. 2010. Policy borrowing, policy learning: Testing times in Australian schooling. Critical Studies in Education 51, no. 2: 129-47.

LLUK. 2011. Review of Qualifications for Learning Professionals in England: Phase 2 Review Summary Document. London: LLUK.

LLUK. 2009. College Workforce Data for England: An Analysis of the Staff Individualised Record Data 2008-2009. http://www.lluk.org/documents/SIR_Report_200809_FINAL.pdf.

Lucas, N. and Nasta, T. 2010. State regulation and the professionalisation of further education teachers: a comparison with schools and HE. Journal of Vocational Education and Training 62, no. 4: 441-454.

Lucas, Norman; Nasta, Tony and Lynne Rogers. 2010. From fragmentation to chaos? The regulation of initial teacher training in further education. Paper presented at the British Education Research Association, September 2-4, in Warwick University.

Menter, I., Hulme, M., Elliot, D. and Lewin, J. with Baumfield, V., Britton, A., Carroll, M., Livingston, K., McCulloch, M., McQueen, I., Patrick, F. and Townsend, T. 2010. Literature Review on Teacher Education in the $21^{\text {st }}$ Century. Edinburgh: Scottish Government Social Research.

Nasta, T. (2007). Translating national standards into practice for the initial training of Further Education teachers in England. Research in Post-Compulsory Education, 12, no. 1: 1-17. 
Ofsted 2010. The Annual Report of Her Majesty's Chief Inspector of Education, Children's Services and Skills 2009/10. London: Ofsted.

Ofsted 2009. The Initial Training of Further Education Teachers - A Survey. London: Ofsted.

Ofsted 2007. Initial Teacher Training in Vocational Subjects. London: Ofsted.

Ofsted 2006. The Logical Chain: Continuing Professional Development in Effective Schools. London: Ofsted.

Ofsted 2003. The Initial Training of Further Education Teachers - A Survey. London: Ofsted.

Power, C. 2007. Educational research, policy and practice in an era of globalisation. Educational Research for Policy and Practice 6: 87-100.

Sahlberg, P., and Boce, E. 2010. Are teachers teaching for a knowledge society? Teachers and Teaching 16, no. 1: 31-48.

Seidel, T. and Shavelson, R. 2007. Teacher effectiveness research in the past decade: The role of theory and research design in disentangling meta-analysis results. Review of Educational Research 77, no. 4: 454-499.

Skills Commission. 2009. Teacher Training in Vocational Education. http:www.policyconnect.org.uk.

Smith, I., Brisard, E. and Menter, I. 2006. Models of partnership developments in initial teacher education in the four components of the United Kingdom: recent trends and current challenges. Journal of Education for Teaching 32, no. 2: 147-164.

Smithers, Alan and Pamela Robinson. (2010). The Good Teaching Guide 2010. Buckingham: CEER.

Stobart, Gordon. 2008. Testing times: The uses and abuses of assessment. London: Routledge.

TDA 2007. Professional Standards for Teachers: Qualified Teacher Status. London: TDA.

Walter, M., Jeffes, J.,Hart, R., Lord, P. and Kinder, K. 2011. Making the Links between Teachers' Professional Standards, Induction, Performance Management and Continuing Professional Development. DfE: London.

Wolf, A. 2011. Review of Vocational Education - the Wolf Report. London: DfE. 